\title{
Combination of diatomaceous earth and powder deltamethrin for insect control in stored corn ${ }^{1}$
}

\author{
Fabiane Cristina Ceruti ${ }^{2,3} \&$ Sonia Maria Noemberg Lazzari ${ }^{2,3}$
}

${ }^{1}$ Contribution $n^{\circ} 1546$ of the Departamento de Zoologia, Universidade Federal do Paraná.

2Departamento de Zoologia, Universidade Federal do Paraná. Caixa Postal 19020, 81531-980 Curitiba-PR, Brasil. lazzari@ufpr.br; biaceruti@ufpr.br

${ }^{3}$ Bolsistas do CNPq.

\begin{abstract}
Combination of diatomaceous earth and powder deltamethrin for insect control in stored corn. The use of diatomaceous earth (DE) is a very efficient insect control measure in stored grain IPM due to its low cost, easy application, reduction of active ingredient residues, lower environmental contamination and operator safety. The objective of this research was to evaluate the efficacy of different dosages of DE mixed with powder deltamethrin for controlling Sitophilus zeamais in stored corn. Samples of $100 \mathrm{~g}$ of clean and dry corn, in three replicates, were submitted to the following treatments: DE (Keepdry $\left.{ }^{\circledR}\right)$, at the dosages of 500,750 and $1000 \mathrm{~g} / \mathrm{t}$; powder deltamethrin (K-Obiol $\left.{ }^{\circledR}\right)$ at $0,5 \mathrm{~g}$ a.i. $/ \mathrm{t}$ and $1,0 \mathrm{~g}$ a.i. $/ \mathrm{t}$; and combinations of the lowest and highest DE dosages with the two dosages of deltamethrin. Thirty adults of $S$. zeamais were placed in each vial with the treated grains and kept in environment chambers at $25^{\circ} \mathrm{C}$. Mortality was evaluated from the $1^{\text {st }}$ to the $28^{\text {th }}$ day. In the treatments mixing DE with deltamethrin or deltamethrin alone, the mortalyti was registered since the first day. In the treatments using only DE, the first dead insects were recorded after the $3^{\text {rd }}$ day, especially in the highest dosages. After the $7^{\text {th }}$ day, however, there was no statistical difference among all treatments, except for the lowest dosage of DE which reached a satisfactory control level only by the $14^{\text {th }}$ day. It was concluded that treatments using DE combined with low dosages of powder deltamethrin represent an efficient control measure against $S$. zeamais in stored corn because insect mortality is faster than in treatments using DE alone and residues of active ingredients are much lower than using the insecticide in high dosages.
\end{abstract}

\begin{abstract}
KEYWORDS. Grain storage; inert dust; insecticide; Sitophilus zeamais.
RESUMO. Combinação de terra de diatomácea e deltametrina em pó para o controle de insetos em milho armazenado. O uso de terra de diatomácea (TD) representa uma medida de controle importante em programas de MIP de armazenamento devido ao baixo custo, facilidade de aplicação, redução do nível de resíduos de ingrediente ativo e da contaminação ambiental e maior segurança para o operador. O objetivo desta pesquisa foi avaliar a eficácia da combinação de diferentes dosagens de TD com deltametrina em pó para o controle de Sitophilus zeamais em milho armazenado. Amostras de 100 g de milho limpo e seco, em três repetições, foram submetidas aos seguintes tratamentos: TD (Keepdry ${ }^{\circledR}$ ), nas dosagens de 500,750 e $1000 \mathrm{~g} / \mathrm{t}$, deltametrina em pó $\left({\mathrm{K}-\mathrm{Obiol}^{\mathbb{}}}^{\mathrm{T}}\right.$ ) a $0,5 \mathrm{~g}$ i.a./t e 1,0 g i.a./t; combinações das dosagens maior e menor de TD com as duas de deltametrina. Em cada frasco foram colocados 30 adultos de $S$. zeamais, mantidos a $25^{\circ} \mathrm{C}$. A mortalidade foi avaliada do $1^{\circ}$ ao $28^{\circ}$ dia. Nos tratamentos utilizando somente TD, a mortalidade foi registrada a partir do $3^{\circ}$ dia sem diferença significativa entre as dosagens até o $7^{\circ}$ dia. Nos tratamentos com deltametrina em pó (isoladamente ou combinada com TD) foram registrados insetos mortos já no $1^{\circ}$ dia após a aplicação. Porém, no $7^{\circ}$ dia não havia diferença entre a maioria dos tratamentos, e no $14^{\circ}$ dia todos atingiram mortalidade elevada sem diferença estatística, incluindo a TD na dosagem mais baixa. Concluiu-se que os tratamentos combinando TD com baixas dosagens de deltametrina são eficientes no controle de $S$. zeamais em milho armazenado porque aceleram a mortalidade dos insetos e reduzem os resíduos de ingredientes ativos.
\end{abstract}

PALAVRAS-CHAVE. Grãos armazenados; inseticida; pós inertes; Sitophilus zeamais.

The concerns with food quality and environmental protection have caused the search for alternative and integrated insect control measures.

Among several kinds of inert dusts, the diatomaceous earth (DE) has a great potential for controlling urban and stored product pests and has been studied by many researchers worldwide (Subramanyam et al. 1989; Aldryhim 1990, 1993; Arthur \& Zettler 1991; Lorini \& Scheneider 1994; Arthur 1996, 2002; Golob 1997; Korunic et al. 1998; Rupp et al. 1998; Subramanyam et al. 1998; Fields 2000; Mewis \& Ulrichs 2001). Commercial formulations of DE are registered in the USA as insecticide and feed addictive (Banks \& Fields 1995) and as insecticide class IV, in Brazil (Lorini 2001).
According to Mital \& Wrightman (1989) and Arthur (1996), the interest in DE has increased because the number of active ingredients for insect control in stored products is reduced to four or five products due mainly to insecticide resistance problems.

Subramanyam et al. (1998) observed that significant reduction in the emergence of Tribolium castaneum (Herbst, 1797) (Coleoptera, Tenebrionidae), Oryzaephilus surinamensis (Linnaeus, 1758) (Coleoptera, Silvanidae) and Plodia interpunctella (Hübner, 1813) (Lepidoptera, Pyralidae) occur in bulk corn when treated with DE. They demonstrated that the first larval instar is the most susceptible to DE application.

The maize weevil, Sitophilus zeamais Motschulsky, 1855 
(Coleoptera, Curculionidae), is the main primary pest of corn, especially, in tropical areas. It also attacks wheat, rice and sorghum grain and processed cereals, as pasta and dehydrated cassava (Dobie et al. 1984). These insects are very active and can infest the grain in the field and in storage (Pacheco \& Paula 1995) and always have to be controlled because of their high biotic potential.

Pinto Jr. (1994), testing four dosages of DE in laboratory, obtained $78 \%$ of mortality for Sitophilus spp. and 100\% for Cryptolestes spp., respectively, by the $9^{\text {th }}$ and $19^{\text {th }}$ days after treatment. The dosages of 750, 1000 and $1250 \mathrm{~g} / \mathrm{t}$ presented the best results.

Ling et al. (1998) compared several dosages of a commercial formulation of DE to control Rhyzopertha dominica (Fabricius, 1792) (Coleoptera, Bostrichidae) in stored rice. They concluded that $500 \mathrm{~g} / \mathrm{t}$ presented a satisfactory control, but only with 700 $\mathrm{g} / \mathrm{t}$ the progeny production was suppressed.

Rupp et al. (1998) observed that either DE applied as dry powder or slurred on the grain in the conveyor belt are efficient to control insects in malting barley. However, adjustments of the application equipment are necessary to avoid abrasion and to improve the results.

The efficacy of DE was improved when it was mixed with pirimiphos-methyl and deltamethrin against Prostephanus truncatus (Horn) (Coleoptera, Bostrichidae) (Barbosa et al. 1994). Bridgeman (2000) also obtained satisfactory results when DE was combined with fumigation.

McLaughlin (1995) points out that the contact insecticides cause a fast immobilization and death of insects, on the other hand inert dusts, such as DE, act in a progressive way, from 15 to 20 days to show an effective insect control. This author verified that Sitophilus granarius (Linnaeus) (Coleoptera, Curculionidae) is one of the most tolerant insect to DE.

Since the action of DE does not depend on metabolic reactions as the chemical insecticides do, the exposed insects do not develop resistance, however they can present behavioral responses, avoiding the contact with the product (Ebeling 1971). The potential of insects to show tolerance, physiological and behavioral resistance to DE was discussed by Korunic \& Ormesher (2000). They observed that insect populations may increase the tolerance to DE when exposed by several generations.

The objective of this research was to evaluate the efficacy of different dosages of DE and of powder deltamethrin and of both products mixed together for the control of $S$. zeamais in stored corn.

\section{MATERIAL AND METHODS}

The experiments were carried out in environmental chambers at $25^{\circ} \mathrm{C}$ and relative humidity of the air of $65 \pm 10 \%$ and 12 hours of photophase.

The DE used for the experiments was the commercial product Keepdry®, which characteristics are: 88 to $90 \%$ of $\mathrm{SiO}_{2}$; particles of 10-15 $\mu \mathrm{m}$; apparent density of 200-230 g/L; color beige, aspect of a dry loose light powder, insoluble in water and free from strange materials. The chemical insecticide was deltamethrin (K-Obiol ${ }^{\circledR}$ - $\left.2 \mathrm{P}\right)$ in a powder formulation.

Different dosages of each insecticide product were homogenenized with clean dry corn kernels with moisture content of $13 \%$. Three replicates of $100 \mathrm{~g}$ of grains were used for each treatment, placed in plastic vials covered with a fine screen lid. In each vial were placed 30 non-sexed adults of $S$. zeamais from 7 to 14 days of age. The treatments were maintained in the chambers and observed daily for 28 days to record the mortality.

The treatments were the following:

1) Diatomaceous earth: in the dosages of $500 \mathrm{~g} / \mathrm{t}$ (T1), $750 \mathrm{~g} / \mathrm{t}$ (T2) and $1000 \mathrm{~g} / \mathrm{t}$ (T3);

2) Combinations of diatomaceous earth (DE) with powder deltamethrin (D): DE $500 \mathrm{~g} / \mathrm{t}+$ D 0,5 g a.i./t (T4); DE $1000 \mathrm{~g} / \mathrm{t}+$ D 0,5 g a.i./t (T5); DE $500 \mathrm{~g} / \mathrm{t}+$ D 1,0 g a.i./t (T6); DE $1000 \mathrm{~g} / \mathrm{t}+$ D 1,0 g a.i./t (T7);

3) Powder deltamethrin: two dosages $0,5 \mathrm{~g}$ a.i./t (T8) and 1,0 g a.i./t (T9);

4) Control (C): without treatment, only the grains with the insects.

For all treatments, the mortality was evaluated in the $1^{\text {st }}$, $3^{\text {rd }}, 7^{\text {th }}, 14^{\text {th }}$ and $28^{\text {th }}$ day. The insects were considered dead when they did not move when touched with a brush, for two minutes.

The experimental design was totally randomized with three replicates. The mean mortality and the standard error (SE) were calculated for each sampling date. The data were analyzed by the variance analysis and the Tukey test at $5 \%$ of probability, using the program SAEG (Universidade Federal de Viçosa $\mathrm{MG})$.

\section{RESULTS AND DISCUSSION}

The mortality was significantly affected by the doses of DE, of deltamethrin and by the exposure time (Table I). In the treatments using only DE, the mortality of $S$. zeamais started in the $3^{\text {rd }}$ day after treatment (Table II, Fig. 1) and by the $14^{\text {th }}$ day there was significant difference between the dosage of $500 \mathrm{~g} / \mathrm{t}$ and the two highest dosages. The accumulated mortality in the $14^{\text {th }}$ day was of $94 \%$ at $500 \mathrm{~g} / \mathrm{t}$ and $98 \%$ at 750 $\mathrm{g} / \mathrm{t}$ and $1000 \mathrm{~g} / \mathrm{t}$ of DE. The mortality was $73 \%$ in the $28^{\text {th }}$ day in the control vials.

These results agree with those obtained by Pinto Jr. (1994), that there is an interaction between the dosages of DE and the exposure time in the mortality of Sitophilus spp., in corn grain. The author registered $100 \%$ of mortality after 19 days of exposure to 500 and $750 \mathrm{~g} / \mathrm{t}$ of DE. Lorini \& Schneider (1994) obtained 19; 87 and $100 \%$ of mortality for S. oryzae with 500; 750 and $1000 \mathrm{~g} / \mathrm{t}$, respectively, after seven days of treatment with DE.

In the treatments mixing DE with deltamethrin, the mortality of $S$. zeamais was affected by the dosages and by the exposure time. Dead insects were registered in the $1^{\text {st }}$ day after the application (Table II, Fig. 1). The accumulated mortality in the $3^{\text {rd }}$ day was: $81 \%$ with the lowest dosage of DE and 


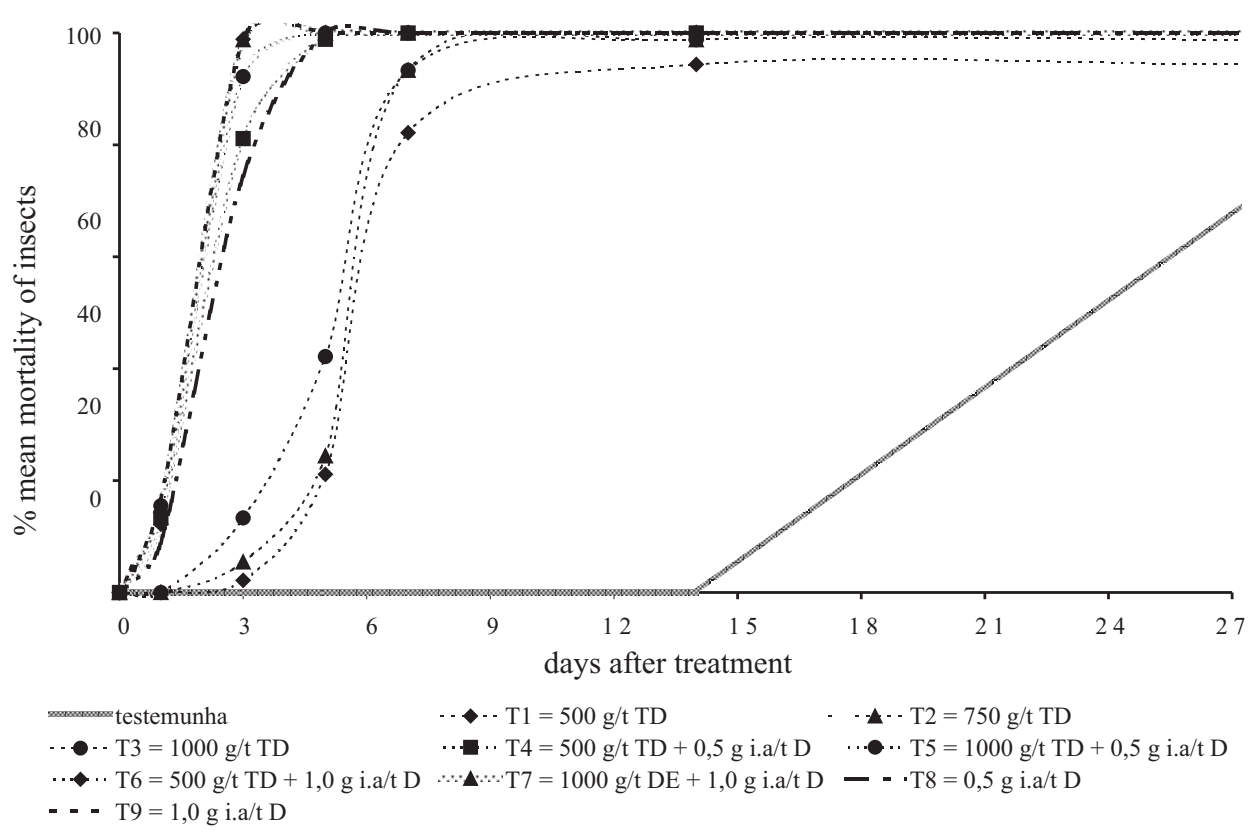

Fig. 1 - Mean mortality of Sitophilus zeamais (initial number $=30$ adults) in treatments of corn: control without treatment, diatomaceous earth (Keepdry $\left.{ }^{\circledR}\right)$ in the dosages of $500 \mathrm{~g} / \mathrm{t}(\mathrm{T} 1), 750 \mathrm{~g} / \mathrm{t}(\mathrm{T} 2)$ and $1000 \mathrm{~g} / \mathrm{t}(\mathrm{T} 3)$, diatomaceous earth mixed with deltamethrin (K-Obiol $\left.{ }^{2}\right)(\mathrm{T} 4$, T5, $\mathrm{T} 6, \mathrm{~T} 7)$ and deltamethrin alone (T8, T9), at $25^{\circ} \mathrm{C}$.

deltamethrin; $92 \%$ with $1000 \mathrm{~g} / \mathrm{t}+0,5 \mathrm{~g} / \mathrm{t} ; 99 \%$ with $500 \mathrm{~g} / \mathrm{t}+$ $1,0 \mathrm{~g} / \mathrm{t}$ and $1000 \mathrm{~g} / \mathrm{t}+1,0 \mathrm{~g} / \mathrm{t} ; 74 \%$ in the lowest dosage and $99 \%$ in the highest dosage of deltamethrin. By the $5^{\text {th }}$ day there was not significant difference among the treatments $\mathrm{T} 4$ and T9. In the control, the mortality was registered only by the $28^{\text {th }}$ day, with $73 \%$, probably due to the condition of the grain that started to deteriorate. By the $7^{\text {th }}$ day after treatment, the difference among treatments was not significant.

Paula (2001) obtained effective control of $S$. oryzae, $R$. dominica and C. ferrugineus with application of DE $(500 \mathrm{~g} / \mathrm{t})$ and pyrimiphos-methyl $(12 \mathrm{~mL} / \mathrm{t})$ in stored rice. Since the mortality with pyrimiphos-methyl was faster than with DE, there was no production of progeny, while a second generation of those insects was produced under the DE treatment, but in numbers lower than that in the control.

An efficient control with DE at $1500 \mathrm{~g} / \mathrm{t}$ against malting barley insects, comparable to the treatment with deltamethrin, was obtained by Rupp et al. (1998).

Ling et al. (1998) compared a formulation of DE with the insecticide fenitrothion against $R$. dominica in paddy rice,

Table I - Square of the variance analysis for treatments with different doses of diatomaceous earth with deltamethrin or DE and deltamethrin alone for controlling Sitophilus zeamais in stored corn.

\begin{tabular}{lcccc}
\hline Causes of the variation & G.L & Q.M. & F Value & Prob. > F \\
\hline Treatment & 9 & 10733.0 & 2094.7 & 0.00001 \\
Days & 5 & 31876.0 & 6221.2 & 0.00001 \\
Treatment*Days & 45 & 1337.8 & 261.0 & 0.00001 \\
Residue & 120 & 5.1 & - & - \\
\hline Variation coefficient & \multicolumn{5}{c}{$3,35 \%$} \\
\hline
\end{tabular}

and obtained 97 and $95 \%$ of mortality, respectively. For $S$. oryzae, the authors observed that this species died in the first eight days. In the control, they observed a progeny higher than in the treatments with both products.

When deciding between a chemical insecticide and DE for insect control, the advantage and disadvantage of both should be considered. The action of chemical insecticides is faster reducing the chances of reproduction and consequently the production of a second generation. However, the selective

Table II - Mean percentage of accumulated mortality of Sitophilus zeamais in ten treatments of corn kernels: control $(\mathrm{C}=$ without application), three dosages of diatomaceous earth (T1, T2, T3), four combinations of diatomaceous earth and deltamethrin (T4, T5, T6, T7) and two of deltamethrin (T8, T9), kept at $25^{\circ} \mathrm{C}$.

\begin{tabular}{ccccccc}
\hline $\begin{array}{c}\text { Days } \\
\text { after } \\
\text { treatment }\end{array}$ & 1 & 3 & 5 & 7 & 14 & 28 \\
\hline $\mathrm{C}$ & $0 \mathrm{C}$ & $0 \mathrm{~F}$ & $0 \mathrm{D}$ & $0 \mathrm{D}$ & $0 \mathrm{~B}$ & $73.3 \mathrm{~B}$ \\
$\mathrm{~T} 1$ & $0 \mathrm{C}$ & $2.2 \mathrm{~F}$ & $21.1 \mathrm{C}$ & $82.2 \mathrm{C}$ & $94.4 \mathrm{~A}$ & $94.4 \mathrm{~A}$ \\
$\mathrm{~T} 2$ & $0 \mathrm{C}$ & $5.5 \mathrm{~F}$ & $24.4 \mathrm{C}$ & $93.3 \mathrm{~B}$ & $98.8 \mathrm{~A}$ & $98.8 \mathrm{~A}$ \\
$\mathrm{~T} 3$ & $0 \mathrm{C}$ & $13.3 \mathrm{E}$ & $42.2 \mathrm{~B}$ & $93.3 \mathrm{~B}$ & $98.8 \mathrm{~A}$ & $98.8 \mathrm{~A}$ \\
$\mathrm{~T} 4$ & $13.3 \mathrm{AB}$ & $81.1 \mathrm{C}$ & $98.8 \mathrm{~A}$ & $100 \mathrm{~A}$ & $100 \mathrm{~A}$ & $100 \mathrm{~A}$ \\
$\mathrm{~T} 5$ & $15.5 \mathrm{~A}$ & $92.2 \mathrm{~B}$ & $100 \mathrm{~A}$ & $100 \mathrm{~A}$ & $100 \mathrm{~A}$ & $100 \mathrm{~A}$ \\
$\mathrm{~T} 6$ & $12.2 \mathrm{AB}$ & $98.8 \mathrm{~A}$ & $100 \mathrm{~A}$ & $100 \mathrm{~A}$ & $100 \mathrm{~A}$ & $100 \mathrm{~A}$ \\
$\mathrm{~T} 7$ & $15.5 \mathrm{~A}$ & $98.8 \mathrm{~A}$ & $100 \mathrm{~A}$ & $100 \mathrm{~A}$ & $100 \mathrm{~A}$ & $100 \mathrm{~A}$ \\
$\mathrm{~T} 8$ & $8.8 \mathrm{~B}$ & $74.4 \mathrm{D}$ & $100 \mathrm{~A}$ & $100 \mathrm{~A}$ & $100 \mathrm{~A}$ & $100 \mathrm{~A}$ \\
$\mathrm{~T} 9$ & $16.6 \mathrm{~A}$ & $98.8 \mathrm{~A}$ & $100 \mathrm{~A}$ & $100 \mathrm{~A}$ & $100 \mathrm{~A}$ & $100 \mathrm{~A}$ \\
\hline C. V $\%$ & $3.35 \%$ & \multicolumn{7}{c}{} \\
\hline
\end{tabular}

Means followed by the same letter in the columns, do not differ to each other by the Tukey test, at $5 \%$ of probability

* C. V. $\%=$ coefficient of variation at $95 \%$ 
pressure of the insecticides results in the development of resistance. High dosages of insecticides also leave residues in the grain and processed end products and cause environmental contamination. The DE is non-toxic and do not leave residues neither contaminants in the environment. However, its action is slower than that of chemical insecticides and the insects may reproduce and leave progeny, but since it stays adsorbed on the grain the residual action will continue to keep the population in low numbers.

\section{CONCLUSIONS}

Dosages of $750 \mathrm{~g} / \mathrm{t}$ and $1000 \mathrm{~g} / \mathrm{t} \mathrm{DE}$ are effective to control S. zeamais in stored corn;

The mortality caused by deltamethrin is significantly higher than that by DE already in the first day after application; mortality caused by DE starts to increase by the $5^{\text {th }}$ day and after the $7^{\text {th }}$ day there is no statistical difference among treatments;

All treatments, including the three dosages of $\mathrm{DE}$, alone or combined of this with powder deltamethrin and deltamethrin alone present high mortality by the $14^{\text {th }}$ day of application; after that there is no statistical differences among treatments;

The mixture of DE with deltamethrin, even in the lowest dosage of both, keeps the population of $S$. zeamais at low levels, without the disadvantages of the full dosage of this chemical insecticide.

\section{REFERENCES}

Aldryhim, Y. M. 1990. Efficacy of amorphous silica dust, Dryacide ${ }^{\circledR}$, against Tribolium confusum Duv. and Sitophilus granarium (L.) (Coleoptera: Tenebrionidae and Curculionidae). Journal of Stored Product Research 26: 207-210.

Aldryhim, Y. M. 1993. Combination of classes of wheat and environmental factors affecting the efficacy of amorphous silica

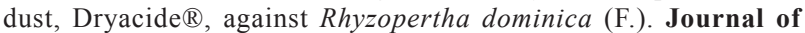
Stored Product Research 29: 271-275.

Arthur, F. H. 1996. Grains Protectans: current status and prospects for the future. Journal of Stored Product Research 32: 293-302.

Arthur, F. H. 2002. Survival of Sitophilus oryzae (L.) on wheat treated with diatomaceous earth: impact of biological and environmental parameters on product efficacy. Journal of Stored Product Research 38: 305-313.

Arthur, F. H.; Zettler, J. L.1991. Malathion resistance in Tribolium castaneum (Coleoptera: Tenebrionidae): differences between discriminating concentrations by topical application and residual mortality on treated surfaces. Journal of Economic Entomology 84: $721-726$.

Banks, H. J.; Fields, P. G. 1995. Stored-grain Ecosystems. In: JAYAS, D. S.; WHITE, N. D. G.; MUIR, W. E. (Eds.) Physical methods for insect control in stored-grain ecosystem. New York: Marcell Dekker, p. 353-409.

Barbosa, A.; Golob, P.; Jenkins, N. 1994. Silica aerogels the alternative protectants of maize against Prostephanus truncatus (Horn) (Coleoptera: Bostrichidae) infestations. In: Proceedings 6 $^{\text {th }}$ International Working Conference on Stored-Product Protection, Canberra 2: 623-627.

Bridgeman, B. W. 2000. Application technology and usage patterns of diatomaceous earth in stored product protection. In: Proceedings $7^{\text {th }}$ International Working Conference on Stored-Product Protection 1: 785-789.

Dobie, P.; Haines, C. P.; Hodges, R. J.; Prevett, P. F. 1984. Insects and arachnids of tropical stored products, their biology and identification: the manual training. UK, Tropical Development and Research Institute, 273 p.

Ebeling, W. 1971. Sorptive dusts goes pest control. Annual Review of the Entomological Society 16: 123-158.

Fields, P. G. 2000. Diatomaceous earth: advantages and limitations. In: Proceedings $7^{\text {th }}$ International Working Conference on Stored-Product Protection 1: 781-784.

Golob, P. 1997. Current status and future perspectives for inert dusts for control of stored products insects. Journal of Stored Product Research 33: 69-79.

Korunic, Z.; Cenkowski, S.; Fields, P. 1998. Grain bulk density affected by diatomaceous earth and application method. Postharvest Biology and Technology 13: 81-89.

Korunic, Z. \& Osmesher, P. 2000. Evaluation and standardised testing of diatomaceous earth. In: Proceedings $7^{\text {th }}$ International Working Conference on Stored-Product Protection 1: 738744.

Ling, Z.; Zhangui, Q.; Korunic, Z. 1998. Field and laboratory experiments with Protect-It ${ }^{\mathrm{TM}}$, and enhanced diatomaceous earth. In: Proceeding $7^{\text {th }}$ International Working Conference on Stored-Product Protection, Beijing 1: 745-757.

Lorini, I.; Schneider, S. 1994. Pragas de grãos armazenados: resultados de pesquisa. Passo Fundo. Embrapa - CNTP, RS, 48 p.

Lorini, I. 2001. Manual Técnico para o MIP de Grãos de Cereais Armazenados. Passo Fundo - RS: Embrapa Trigo, 80 p.

McLaughlin, A. 1995. Dryacide sorptive dust insecticide. In: Proceedings $6^{\text {th }}$ International Working Conference on Stored Product Protection, Canberra 2: 638-645.

Mewis, I. \& Ulrichs, C. 2001. Action of amorphous diatomaceous earth against different stages of the stored product pest Tribolium confusum, Tenebrio molitor, Sitophilus granarius e Plodia interpunctella. Journal of Stored Product Research 37: 153164.

Mital, S.; Wrightman, J. A. 1989. An inert dust protects stored groundnuts from insects pest. ICRISAT. Newsletter, p. 21-22.

Pacheco, I. A. \& Paula, D. C. 1995. Insetos de grãos armazenados - Identificação e Biologia. Campinas, Fundação Cargill, 228 p.

Pinto JR., A. R. 1994. Uso de pós inertes no controle de insetos de grãos armazenados. Curitiba. Dissertação de Mestrado em Entomologia, UFPR. $80 \mathrm{p}$.

Rupp, M. M. M.; Lazzari, F. A.; Lazzari, S. M. 1998. Manutenção da qualidade de cevada armazenada: Efeito do uso do pó inerte no controle de insetos que ocorrem em sementes de cevada. In: Reunião Anual de Pesquisa de Cevada, Passo Fundo - RS, 17: $302-307$.

Subramanyam, BH.; Harein, P. K.; Cutkomp, L. K. 1989. Organophosphate resistance in adults of red flour beetle (Coleoptera: Tenebrionidae) and saw toothed grain beetle (Coleoptera: Cucujidae) infesting barley stored on farms in Minnesota. Journal of Economic Entomology 82: 989-995.

Subramanyam, BH.; Madamanchi, N.; Norwood, S. 1998. Effectiveness of Insecto ${ }^{\circledR}$ applied to shelled maize against stored product insect larvae. Journal of Economic Entomology 91: 280-286. 